\author{
Marcin Kamiński \\ Jagiellonian University in Cracow \\ marcin.kaminski@uj.edu.pl \\ ORCID ID: https://orcid.org/0000-0001-9181-2044
}

\title{
Internal and External Limits of the Principle of Consistent Interpretation of Domestic Law with the Directives of the European Union and Their Relevance for the Adjudication of the Administrative Courts
}

\begin{abstract}
This article examines the issues of external and internal limits of the consistent interpretation of the domestic law with the EU directives in the context of verification adjudication of the administrative courts. The external limits of the pro-directive interpretation are derived from the EU law and the case-law of the Court of Justice of the EU. The limits of the pro-directive interpretation can as well be derived from the domestic law of the member states (the internal limits). This kind of limitations is strictly connected with domestic limits of the judicial interpretation. In the considerations it is argued that the pro-directive interpretation which goes beyond the literal meaning of domestic provisions could not be treated as being contrary to the domestic law. In the case-law of administrative courts the necessity of functional, purposive and axiological meaning of the contra legem limit is especially significant. It is justified to state that consistent interpretation must embrace operations of interpretation secundum legem and praeter legem. Therefore, the domestic contra legem limit is shaped and modified by the EU rules of interpretation.

Keywords: consistent interpretation of the domestic law with the EU directives; limits of the pro-directive interpretation; direct and indirect effects of the EU directives; supremacy of EU law; interpretation secundum legem, praeter legem and contra legem
\end{abstract}

\section{Introductory remarks}

The issue of the consistent interpretation of domestic law with the directives of the European Union is a fragment of the broader question of interpretation of domestic law in conformity with the European Union law (EU law). Since the European legal order is multi-level and complex, therefore the problem of the pro-European Union 
interpretation of national laws of the member states is to be considered at three different levels ${ }^{1}$.

At the first level, there is the legal obligation to interpret primary EU law in the light of the obligations of the European Union (EU) as an international organisation (first of all - in the light of treaties which have been concluded by the EU or which have binding force for the EU). At the second level, there is the legal duty to interpret secondary EU law (e.g. regulations, directives, decisions) in conformity with the primary EU law. And thirdly, the domestic law of the member states of the EU must be interpreted in the light of the wording and purpose of European Union law.

The analysed issue pertains to the third level of domestic law interpretation in the conformity with the EU law. Furthermore, the abovementioned notion is limited to the directives as specific instruments and sources of the secondary EU law. Therefore, the consistent interpretation of domestic law with the directives of the European Union must be treated as a special kind of pro-EU interpretation of domestic law ${ }^{2}$. The above interpretative model retains the qualitative and quantitative differences compared to the general model of pro-EU interpretation.

\section{Normative sources of the principle of interpretation in conformity with the EU directives}

The conceptual construction of the interpretation in conformity with the EU directives is the result of validity of the general principles of EU law. There is no doubt that the considered construction has been merged in the EU law as a logical and functional consequence of fundamental features of the EU legal order. The doctrine of consistent interpretation is anchored in at least two basic principles of EU law ${ }^{3}$.

Firstly, one may indicate the principle of supremacy (primacy) of EU law over the national law of member states ${ }^{4}$. The essence of this principle lies in a specific mode of resolving normative contraries or inconsistencies between the EU law and the legal orders of member states. In the situation of the normative conflict in a concrete matter in which the EU law and national law are to be used, the norm of EU law prevails and the domestic norm must not be applied. Secondly, one may argue that the doctrine of consistent interpretation is derived from the principle of effectiveness of the $\mathrm{EU}$

1 J.H. Jans, R. de Lange, S. Prechal, R.J.G.M. Widdershoven (eds.), Europeanisation of Public Law, Groningen 2007, p. 99.

2 See e.g. C. Herrmann, Richtlinienumsetzung durch Rechtsprechung, Berlin 2003, pp. $102 \mathrm{ff}$.

3 See e.g. A. Wróbel, Wykładnia prawa państwa członkowskiego zgodnie z dyrektywą, czyli tzw. pośredni skutek dyrektywy, (in:) A. Wróbel (ed.), Stosowanie prawa Unii Europejskiej przez sądy. Tom I, Warszawa 2010, pp. $110 \mathrm{ff}$.

4 T. Kruis, Der Anwendungsvorrang des EU-Rechts in Theorie und Praxis: seine Durchsetzung in Deutschland. Eine theoretische und empirische Untersuchung anhand der Finanz- und Verwaltungsgerichte und Behörden, Tübingen 2013, pp. $155 \mathrm{ff}$. 
Internal and External Limits of the Principle of Consistent Interpretation of Domestic...

law and the latter principle is even - in the area of the interpretation in conformity with the EU directives - more important than the principle of supremacy. The approach of this sort seems to be justified since as far as the principle of supremacy is the source of primacy of application of the EU directive norms which are vertically directly effective, the principle of interpretation in conformity with the EU directives is applicable not only in vertical configurations but also in horizontal ones ${ }^{5}$.

\section{Characteristic features of the principle of consistent interpretation}

The doctrine of consistent (harmonious) interpretation is a special and derivative principle of the EU law. This principle is also known as the principle of indirect effect ${ }^{6}$. The EU law norms which are the source of the consistent interpretation of domestic law generally do not involve directly legal effects unless they are directly effective. Therefore, this kind of interpretative influence of the EU law on the national legal orders of member states allows to qualify the EU law norms at least as indirectly effective.

The principle of consistent interpretation has certain characteristic features which determine its essence.

First of all, the above construction has a normative character. The European Court of Justice (ECJ) established the duty of consistent interpretation in the Von Colson and Kamann judgment ${ }^{7}$. With regard to EU directives the ECJ pointed out that "the Member States' obligation arising from a directive to achieve the result envisaged by the directive and their duty under [Article 4(3) Treaty on European Union (TEU)] to take all appropriate measures, whether general or particular, to ensure the fulfilment of that obligation, is binding on all the authorities of Member States including, for matters within their jurisdiction, the courts. It follows that, in applying the national law and in particular the provisions of a national law specifically introduced in order to implement Directive (...), national courts are required to interpret their national law in the light of the wording and the purpose of the directive in order to achieve the result referred to in the third paragraph of [Article 288 Treaty on the Functioning of the European Union (TFEU)]". The above judgment makes clear that the duty of consistent interpretation - regarding the directives - is based on Article 4(3) TEU, stipulating the duty of sincere cooperation, and Article 288 TFEU, requiring the implementation of directives. In the Pfeiffer judgment ${ }^{8}$ the ECJ stated that the duty

5 Cf. M. Franzen, Privatrechtsangleichung durch die Europäische Gemeinschaft, Berlin - New York 1999, p. 294.

6 See e.g. C. Barnard, S. Peers, European Union Law, Oxford 2017, pp. 156 ff.

7 Judgment of the Court of 10 April 1984, Case 14/83, Sabine von Colson and Elisabeth Kamann v. Land Nordrhein-Westfalen, European Court Reports (ECR) 1984, p. 01891.

8 Judgment of the Court of 5 October 2004, in joined Cases C-397/01 to C-403/01, Bernhard Pfeiffer and others v. Deutsches Rotes Kreuz, Kreisverband Waldshut eV., ECR 2004, I-08835, $\$ 114$. 
of consistent interpretation is "inherent in the system of the Treaty, since it permits the national court, for matters within its jurisdiction, to ensure the full effectiveness of Community law when it determines the dispute before it". In many judgments of the ECJ the scope of this duty has been extended to the European Union law as a whole (including EU Treaties, general principles of EU law, regulations and recommendations) $)^{9}$.

Secondly, it should be taken into account that the principle of pro-directive interpretation established the interpretative rule which prevails over the rules and methods of domestic law interpretation ${ }^{10}$. The interpretative priority of the directiveconsistent meaning means that in a case of collision of domestic interpretative rules in the matter which contains the normative component derived from the EU-directive the resolution of this conflict must - as far as possible - provide the advantage of such a result of national law interpretation which fulfils the wording and purpose of directive provisions. Therefore, the national law-applying authorities (e.g. national courts) are required to choose only those interpretative versions of domestic law which are the most compatible with the contents, purposes, functions and axiological assumptions of the EU-directive. A separate issue is the problem of the type and the chronology of application of the interpretative rules. It may be argued that the priority of pro-directive consistent interpretation creates the autonomous and distinct rule $^{11}$. One may also defend the view that this rule of interpretative priority must be observed within the framework of domestic rules and methods of interpretation ${ }^{12}$.

9 See e.g. Judgment of the Court of 5 October 1994, Case C-165/91, Simon J.M. van Munster v. Rijksdienst voor Pensioenen, ECR 1994, Page I-04661, \$ 34; Judgment of the Court of 10 February 2000, in joined Cases C-270/97 and C-271/97, Deutsche Post AG v. Elisabeth Sievers (C-270/97), Brunhilde Schrage (C-271/97), ECR 2000, I-929, \$ 62; Judgment of the Court of 13 December 1989, Case C-322/88, Salvatore Grimaldi v. Fonds des maladies professionnelles, ECR 1989, Page 04407, $₫ 18$; Judgment of the Court of 26 September 2000, Case C-262/97, Rijksdienst voor Pensioenen v. Robert Engelbrecht, ECR 2000, I-07321, \$ 39; Judgment of the Court of 17 January 2008, Case C-246/06, Josefa Velasco Navarro v. Fondo de Garantía Salarial (Fogasa), ECR 2008, I-00105, \$ 39; Judgment of the Court of 13 March 2008, in joined Cases C-384/06 to C-385/06, Vereniging Nationaal Overlegorgaan Sociale Werkvoorziening (C-383/06) and Gemeente Rotterdam (C-384/06) v. Minister van Sociale Zaken en Werkgelegenheid and Sociaal Economische Samenwerking West-Brabant (C-385/06) v. Algemene Directie voor de Arbeidsvoorziening, ECR 2008, I-01561, \$59.

10 Cf. U. Ehricke, Die richtlinienkonforme und die gemeinschaftsrechtskonforme Auslegung nationalen Rechts, "Rabels Zeitschrift für ausländisches und internationales Privatrecht" 1995, vol. 59, p. 616; W. Brechmann, Die richtlinienkonforme Auslegung, München 1994, p. 259; C. Hermann, Richtlinienumsetzung durch..., op. cit., pp. $131 \mathrm{ff}$.

11 See e.g. M. Lutter, Die Auslegung des angeglichenen Rechts, „Juristen-Zeitung” 1992, no. 47, pp. 604 ff.; C.-W. Canaris, Gemeinsamkeiten zwischen verfassungs- und richtlinienkonformer Rechtsfindung, (in:) H. Bauer (ed.), Wirtschaft im offenen Verfassungsstaat. Festschrift für Reiner Schmidt zum 70. Geburtstag, München 2006, p. 49. 
Internal and External Limits of the Principle of Consistent Interpretation of Domestic...

It is also justified to assert that the construction of the pro-directive interpretation is the special kind of domestic law interpretation which combines a variety of features of the literal, systematic and purposive-functional interpretations ${ }^{13}$.

Thirdly, it must be stressed that the requirement of conformity of interpretative result with the directive is not confined to the literal meaning of the directive provisions but must be extended to their purposes and functions ${ }^{14}$. Therefore, it means that the notion of pro-directive conformity provides relatively broad possibilities to ensure the full effectiveness of the European Union law within the limits of domestic law. The approach of this kind has found the corroboration in the conception of the presumption of directive implementation conformity.

The above conception has been formulated in the judgments of the ECJ. The Court has held that every national court must presume that the State had the intention of fulfilling entirely the obligations arising from the directive concerned ${ }^{15}$. The scope of the presumption of compliance is not unlimited.

There are three variants of situations which should be excluded from the scope of the presumption ${ }^{16}$. Firstly, the presumption may not be applied if the legislator intentionally did not transpose the directive into national law at all. Secondly, the presumption is not subject to apply if the legislator expressly refused to implement the directive into national law. Thirdly, a national law-applying organ (court) is not required to presume the intention of proper implementation of the directive if the legislator "neither amended the pre-existing legislation in order to implement the directive nor considered the pre-existing legislation to already satisfy the requirements of the directive".

The construction of the presumption of directive implementation conformity shall be differentiated from the rebuttal of the presumption. The case of the rebuttal covers the situation in which the national court "reaches an outer limit of consistent interpretation". The outer limit of the presumption of compliance defines the contra legem limit of the consistent interpretation. The legal duty of consistent interpretation does not require the court to infringe the prohibition of interpretation contra legem. Therefore, the presumption of compliance must be rebutted in such a situation in order to avoid the violation of the above prohibition. On the other hand, one must

13 See e.g. A. Wróbel, Wykładnia prawa państwa..., op. cit., pp. 116-117, 127-128.

14 See e.g. M. Nettesheim, Auslegung und Rechtsfortbildung nationalen Rechts im Lichte des Gemeinschaftsrechts, „Archiv des öffentlichen Rechts” 1994, vol. 119, pp. 261 ff.

15 Judgment of the Court of 16 December 1993, Case C-334/92, Teodoro Wagner Miret v. Fondo de Garantía Salarial, ECR 1993, I-06911, \$20; Judgment of the Court of 5 October 2004, in joined Cases C-397/01 to C-403/01, Bernhard Pfeiffer and others v. Deutsches Rotes Kreuz, Kreisverband Waldshut eV., ECR 2004, I-08835, \$112.

16 Cf. M. Brenncke, A Hybrid Methodology for the EU Principle of Consistent Interpretation, "Statute Law Review" 2017, vol. 38, forthcoming Issue, available at SSRN: https://papers.ssrn. $\mathrm{com} / \mathrm{id}=2883447$ (access 1.11.2017), pp. 10-18. 
keep in mind that the ECJ stipulated that the duty of interpretation of domestic law in conformity with an applicable directive remains valid irrespective of "any contrary interpretation which may arise from the travaux préparatoires for the national rule"17. It means that the legislative preparatory materials which could have indicated on the intention of the national legislator to enact the provisions incompatible with the directive do not exclude the consistent interpretation of these provisions.

Fourthly, from the point of view of the above analysis, it is important to distinguish two kinds of limits of the interpretation of domestic law in the conformity with directives. The first kind of the limits results from the structural limitations of the EU legal order (these are so-called external limits of the consistent interpretation). The second kind of the limits is based on the certain principles, rules and features of the national legal orders of member states (these are so-called internal limits of the consistent interpretation).

\section{The principle of the consistent interpretation of domestic law with the directives of the European Union in the sphere of administrative courts' adjudication activity}

The issue of the pro-directive interpretation of domestic law - according to the title of the paper - must be related to the specificity of the adjudication activity of the administrative courts.

First of all, it must be borne in mind that the administrative courts' interpretation of national law in the light of the wording and the purpose of the directive takes place within the framework of the domestic model of judicial control of public administration. In accordance with the principle of procedural and structural autonomy ${ }^{18}$ the issues of the structure, the proceedings, the scope of jurisdiction and the principles of adjudication of the administrative courts are determined by the national law of the member states of the EU.

In the Polish legal order, the system of administrative courts is based on the verification model of the judicial control of public administration. At its core such model posits that the administrative court controls the legality (a conformity with

17 Judgment of the Court of 29 April 2004, Case C-371/02, Björnekulla Fruktindustrier AB. v. Procordia Food AB., ECR 2004, I-05791, \$13.

18 E.g. A. Wróbel, Autonomia proceduralna państw członkowskich. Zasada efektywności i zasada efektywnej ochrony sądowej w prawie Unii Europejskiej, "Ruch Prawniczy, Ekonomiczny i Socjologiczny" 2005, No. 1, pp. 35-58; D.-U. Galetta, Procedural autonomy of EU member states: Paradise Lost? A study on the "functionalized procedural competence" of EU member states, Berlin - Heidelberg 2010, pp. 7 ff.; A. Adinolfi, The "Procedural Autonomy" of Member States and the Constraints Stemming from the ECJ's Case Law: Is Judicial Activism Still Necessary?, (in:) B. de Witte, H.-W. Micklitz (eds.), The European Court of Justice and Autonomy of the Member States, Cambridge - Antwerp - Portland 2011, pp. $281 \mathrm{ff}$. 
Internal and External Limits of the Principle of Consistent Interpretation of Domestic...

provisions of binding law) of the challenged administrative action or inaction without the adjudication of an administrative matter on the merits. The verification model is structurally related to the cassation competences of the administrative court. If the complaint is justified the court in principle sets aside or declares the invalidation of the contested action ${ }^{19}$. Controlling the legality of the activity of public administration the court reviews as well the correctness of the interpretation which has been made by the administrative authority. If the administrative interpretation is erroneous (i.e. it violates the law) the administrative court is empowered to substitute its own legal assessment for the interpretation of the controlled administrative authority ${ }^{20}$. The administrative court's power to determine the limits of administrative freedom of the interpretation is also extended to the interpretation of domestic law in accordance with the EU directives.

Since the member states' obligation arising from a directive to achieve the result provided for by the directive is binding first of all on all the national courts (including the administrative courts) ${ }^{21}$, the court controlling the actions (or inactions) of public administration is required to ensure the fulfilment of that obligation by that means so that the judicial interpretation of domestic law in conformity with the applicable directive - as far as possible - must be substituted for the administrative interpretation which is incompatible with the directive and the illegal administration action which has been based on such interpretation must be quashed or invalidated. The court's obligation to deprive the challenged administrative act (action) of its binding force may be derived from the member states' obligation to "setting aside any provision of national law which may conflict with" the EU law and from the competence of the domestic law-applying authority to "refusing of its own motion to apply any conflicting provision" of national law ${ }^{22}$.

The legal duty of national administrative courts has a relatively broad scope. It covers the whole domestic legal order ${ }^{23}$, not only the provisions which have been established in order to implement the directive but also the domestic provisions which may indirectly influence the effectiveness of the EU law. Moreover, it is also

19 See The Act of 30th August 2002 Law on Proceedings before Administrative Courts (Journal of Laws 2017, item 1369 with changes).

20 See Art. $145 \$ 1$ points 1-2 of The Act of 30th August 2002 Law on Proceedings before Administrative Courts.

21 See e.g. Judgment of the Court of 9 March 1978, Case C-106/77, Amministrazione delle Finanze dello Stato v. Simmenthal SpA., ECR 1978, Page 00629, \$20-24; Judgment of the Court of 10 April 1984, Case 14/83, Sabine von Colson and Elisabeth Kamann v. Land Nordrhein-Westfalen, ECR 1984, Page 01891, \$26.

22 Judgment of the Court of 9 March 1978, Case C-106/77, Amministrazione delle Finanze dello Stato v. Simmenthal SpA., ECR 1978, Page 00629, § 21, 24.

23 See e.g. Judgment of the Court of 5 October 2004, in joined Cases C-397/01 to C-403/01, Bernhard Pfeiffer and others v. Deutsches Rotes Kreuz, Kreisverband Waldshut eV., ECR 2004, I-08835, $\$ 115$ and $\$ 119$. 
irrelevant whether these provisions were established before or after the directive entered into force ${ }^{24}$, or whether their interpretation version was stabilized in the caselaw of the highest national courts ${ }^{25}$.

It is also clear that the duty of consistent interpretation is not subject to the condition of direct effectiveness ${ }^{26}$ i.e. the direct effect of directive provisions is not the premise of this duty. The constructions of direct effect and indirect effect of the directive provide for alternative methods of ensuring the effectiveness of EU law. However, these methods with regard to the directive must be used in a specific order ${ }^{27}$.

The administrative court's obligation to interpret the domestic law in conformity with the directive dispositions is actuated in the situation of real or potential incompatibility between the directive and the national law ${ }^{28}$.

Firstly, the national administrative court must consider the possibility of the removal of normative collision by means of the interpretation of domestic law in conformity with the directive ${ }^{29}$. This operation shall be performed by the administrative court irrespective of whether a given directive provision is directly effective or not. Even if the directive provision is directly effective, the consistent interpretation of the domestic law may be sufficient to ensure the EU law the required effectiveness. One must bear in mind that it is difficult to indicate the moment in which the consistent interpretation is transformed into the construction of direct effect $^{30}$. In the case of directive provisions which lack the feature of direct effectiveness the consistent interpretation is, however, in principle the exclusive manner of ensuring the effectiveness of EU law.

If the directive provision fulfils the conditions for it to have direct effect (i.e. the clear, sufficiently precise and unconditional provision seeking to confer rights or impose obligations) and the consistent interpretation in its light is not able to remove

24 Judgment of the Court of 13 November 1990, Case C-106/89, Marleasing SA v. La Comercial Internacional de Alimentacion SA, ECR 1990, I-04135, $\$ 8$; Judgment of the Court of 22 November 2005, Case C-144/04, Werner Mangold v. Rüdiger Helm, ECR 2005, I-09981, 68.

25 Cf. Judgment of the Court of 13 July 2000, Case C-456/98, Centrosteel Srl v. Adipol GmbH, ECR 2000, I-06007, \$ 68 .

26 See e.g. O. Gänswein, Der Grundsatz unionsrechtskonformer Auslegung nationalen Rechts. Erscheinungsformen und dogmatische Grundlage eines Rechtsprinzips des Unionsrechts, Frankfurt am Main 2009, pp. $39 \mathrm{ff}$.

27 Concerning the sequence of above methods - see e.g. W. Brechmann, Die richtlinienkonforme..., pp. $64 \mathrm{ff}$.

28 See more - e.g. M. Kamiński, Mechanizm i granice weryfikacji sądowoadministracyjnej a normy prawa administracyjnego i ich konkretyzacja, Warszawa 2016, pp. $484 \mathrm{ff}$.

29 Cf. O. Gänswein, Der Grundsatz unionsrechtskonformer Auslegung..., op. cit., p. 310.

30 Cf. P. Craig, Directives: Direct Effect, Indirect Effect and the Construction of National Legislation, "European Law Review" 1997, vol. 22, pp. 526 ff. 
Internal and External Limits of the Principle of Consistent Interpretation of Domestic...

the normative conflict ${ }^{31}$, the administrative court is obliged to refuse the application of the domestic law which is inconsistent with the directive ${ }^{32}$.

The refusal of domestic law application has a peculiar character within the framework of the verification model of judicial control of the public administration. Since the administrative court does not adjudicate on the administrative matter in a direct means but only controls the legality of the administrative competence behaviour, therefore it cannot be claimed that this court refuses the application of domestic law. In such a situation the administrative court eliminates the domestic provision - which is incompatible with the directive - from the legal basis of the controlled administrative action ${ }^{33}$. This normative elimination is legally binding for the administrative authority whose act was quashed by the administrative court $^{34}$. The above effect of exclusion ("exclusionary effect of a directive") of the national law (direct negative effect) ${ }^{35}$ creates a normative gap which must be filled by the administrative court. If the directive contains directly effective provisions, the normative gap may and should be closed by means of application of these provisions. This "substitution effect" of a directive ${ }^{36}$ (direct positive effect) enables to modify the domestic normative basis of the administrative action which was controlled by the administrative court. It should be noted that in the literature not without reason it is claimed that the distinction between "exclusion", combined with the residual application of national law, and "substitution", entailing the application of "new" rules derived from the directive, "conceals more than it reveals" ${ }^{37}$, and the limits between negative (exclusion) and positive (substitution) effects of the directive are flexible and elusive $^{38}$.

31 C. Höpfner, Die systemkonforme Auslegung. Zur Auflösung einfachgesetzlicher, verfassungsrechtlicher und europarechtlicher Widersprüche im Recht, Tübingen 2008, pp. $243 \mathrm{ff}$.

32 Judgment of the Court of 4 February 1988, Case C-157/86, Mary Murphy and others v. An Bord Telecom Eireann, ECR 1988, Page 00673, $\$ 11$; Judgment of the Court of 19 June 1990, Case C-213/89, The Queen v. Secretary of State for Transport, ex parte: Factortame Ltd and others, ECR 1990, Page I-02433, \$ 20-23; Judgment of the Court of 5 March 1998, Case C-347/96, Solred SA v. Administración General del Estado, ECR 1998, Page I-00937, § 27; Judgment of the Court of 26 September 2000, C-443/98, Unilever Italia SpA v. Central Food SpA., ECR 2000, Page I-07535, $\S 52$; Judgment of the Court of 24 January 2012, Case C-282/10, Maribel Dominguez v. Centre informatique du Centre Ouest Atlantique i Préfet de la région Centre, ECR 2012, \$ 23.

33 Cf. Judgment of the Court of 22 December 2008, Case C-414/07, Magoora sp. z o.o. v. Dyrektor Izby Skarbowej w Krakowie, ECR 2008, I-10921, \$ 44.

34 Art. 153 of The Act of 30th August 2002 Law on Proceedings before Administrative Courts.

35 See C.W.A. Timmermans, Directives: their effect within the national legal systems, "Common Market Law Review" 1979, vol. 16, pp. 533 ff.

36 Cf. P. Craig, G. de Burca, EU Law. Text, Cases and Materials, Oxford 2011, pp. 210-211.

37 P. Craig, The Legal Effect of Directives: Policy, Rules and Exceptions, "European Law Review" 2009, vol. 34, pp. $368 \mathrm{ff}$.

38 See e.g. P. Brzeziński, Unijny obowiązek odmowy zastosowania przez sąd krajowy ustawy niezgodnej z dyrektywą Unii Europejskiej, Warszawa 2010, pp. 267 ff. 
The discussed problem must be resolved differently with regard to normative components of the directive which are not directly effective ${ }^{39}$.

On the one hand the lack of capability of involving the legal effects entails the necessity of ensuring the effectiveness of EU law by means of lawmaking interpretation of domestic law in conformity with the directive. On the other hand, there is the problem of establishing the legal source of such lawmaking operation.

The above problem results from a deficiency of normative patterns which could be used as the basis to construct of a new version of domestic law in order to achieve the state of conformity with the EU legal order ${ }^{40}$. Moreover, there are the crucial and contentious issues of delimitation between the lawmaking interpretation of domestic law in the light of wording and purpose of directive provisions and the direct effectiveness of these provisions. In the absence of directly effective provisions the operation of too extensive pro-directive interpretation of domestic law could lead to a situation which is comparable with the directive effectiveness ${ }^{41}$. However, the situation of this kind would not be amenable.

\section{The external limits of pro-directive interpretation}

The principle of the consistent interpretation of domestic law with the directives of the European Union is subject to limitations which result from the EU law and the national law ${ }^{42}$.

The limits of the pro-directive interpretation of domestic law which are derived from the EU law (the external limits of pro-directive interpretation) are a consequence of the contents of the primary and secondary EU law and of the essence and structural features of the directive. This kind of limits may be internally divided into four categories ${ }^{43}$.

Firstly, it is justified to distinguish the temporal limits of the pro-directive interpretation of domestic law. The issue of the scope of temporal limits is contentious. In the case C-212/04 Konstantinos Adeneler and Others ${ }^{44}$, the ECJ on the one hand has

39 See e.g. M. Kamiński, Mechanizm i granice weryfikacji..., op. cit., pp. 490 ff.

40 See e.g. T. Kruis, Der Anwendungsvorrang des EU-Rechts..., op. cit., pp. 221 ff., 231-233 and the literature there cited; A. Kalisz, Wykładnia i stosowanie prawa wspólnotowego, Warszawa 2007, pp. $210 \mathrm{ff}$.

41 Cf. e.g. S. Prechal, Directives in EC Law, Oxford - New York 2005, p. 211; M. Lutter, Die Auslegung..., op. cit., p. 597; W. Brechmann, Die richtlinienkonforme..., op. cit., p. 73; A. Kaczorowska, European Union Law, London - New York 2009, p. 323.

42 See e.g. M. Weber, Grenzen EU-rechtskonformer Auslegung und Rechtsfortbildung, Baden Baden 2010, pp. 140 ff; O. Gänswein, Der Grundsatz unionsrechtskonformer Auslegung..., op. cit., pp. 309 ff; T. Kruis, Der Anwendungsvorrang des EU-Rechts..., op. cit., pp. 200 ff.

43 M. Kamiński, Mechanizm i granice weryfikacji..., op. cit., pp. $496 \mathrm{ff}$.

44 Judgment of the Court of 4 July 2006, Case C-212/04, Konstantinos Adeneler and Others v. Ellinikos Organismos Galaktos (ELOG), ECR 2006, I-06057, § 114-124. 
Internal and External Limits of the Principle of Consistent Interpretation of Domestic...

reminded that "before the period for transposition of a directive has expired, Member States cannot be reproached for not having yet adopted measures implementing it in national law (see Case C-129/96 Inter-Environnement Wallonie [1997] ECR I-7411, paragraph 43)". On the other hand, the Court has held that "during the period prescribed for transposition of a directive, the Member States to which it is addressed must refrain from taking any measures liable seriously to compromise the attainment of the result prescribed by it (Inter-Environnement Wallonie, paragraph 45; Case C-14/02 ATRAL [2003] ECR I-4431, paragraph 58; and Mangold, paragraph 67)" and "the obligation to refrain from taking" the above mentioned measures "applies just as much to national courts". That is to imply that "from the date upon which a directive has entered into force, the courts of the Member States must refrain as far as possible from interpreting domestic law in a manner which might seriously compromise, after the period for transposition has expired, attainment of the objective pursued by that directive". Consequently the Court has stated that "where a directive is transposed belatedly into a Member State's domestic law and the relevant provisions of the directive do not have direct effect, the national courts are bound to interpret domestic law so far as possible, once the period for transposition has expired, in the light of the wording and the purpose of the directive concerned with a view to achieving the results sought by the directive, favouring the interpretation of the national rules which is the most consistent with that purpose in order thereby to achieve an outcome compatible with the provisions of the directive".

In the above context it may be noted that national courts have negative and positive pro-directive interpretation duties which are related to the time limit of transposition. From the date upon which a directive has entered into force to the expiry date of the period for transposition the courts have the negative obligation to refrain from interpreting domestic law in a contra-directive manner, whereas after the period for transposition has expired the courts are obliged - in the positive sense - to attain the objective pursued by the directive.

Secondly, it must be taken into account that certain limitations could result from the contents of the directive itself. The national court must consider carefully the scope of the implementation freedom which was bestowed on the domestic legislator ${ }^{45}$. If the scope of this freedom is relatively broad the court is obliged to demonstrate the necessary restraint in the pro-directive interpretation of domestic law. In this situation it may be required to confine the interpretative activism of the courts.

Thirdly, the duty of consistent interpretation is limited by the primary and the secondary EU law, including first of all the structural and general principles of the 
$\mathrm{EU}$ law and the fundamental rights of the $\mathrm{EU}^{46}$. In particular, the national courts' obligation is confined by the principles of legal certainty, non-retroactivity and proportionality ${ }^{47}$.

Fourthly, the construction of pro-directive interpretation is limited by the essential and structural features of the directive and scopes of its validity. In the absence of proper transposition of the directive into national law the consistent interpretation cannot lead to the imposition or the extension of obligations or sanctions on individuals ${ }^{48}$. Consequently, the Member State which has violated the obligation of the directive implementation is not empowered to apply the directive by means of the pro-directive interpretation of domestic law (e.g. in tax law cases), if it would have led to the imposition or the extension of obligations or sanctions on individuals. This approach seeks to prevent "the State from taking advantage of its own failure to comply" with EU law ${ }^{49}$. Furthermore, it is not allowed to apply a clear, precise and unconditional provision of a directive seeking to confer rights or impose obligations on individuals in proceedings exclusively between private parties (the prohibition of direct effectiveness of the directive in horizontal relations) ${ }^{50}$. In the latter case the administrative court controlling the challenged administrative action is obliged to prevent such an interpretation consistent with the unimplemented directive which could lead to the indirect imposition or the extension of obligations on the private persons who are indirect addressees of the administrative action (who would be unfavourably affected by the consistent interpretation). The above situation

46 See e.g. M. Weber, Grenzen EU-rechtskonformer Auslegung..., op. cit., pp. 141 ff; W. Brechmann, Die richtlinienkonforme..., op. cit., pp. $275 \mathrm{ff}$.

47 See Judgments of the Court in the Cases: Criminal proceedings against Kolpinghuis Nijmegen BV., Case 80/86, ECR 1987, Page 03969, \$ 13; Criminal proceedings against Silvio Berlusconi (C387/02), Sergio Adelchi (C-391/02) and Marcello Dell'Utri and Others (C-403/02), Joined cases C-387/02, C-391/02 and C-403/02, ECR 2005, I-03565, \$ 66-69; Konstantinos Adeneler and Others v. Ellinikos Organismos Galaktos (ELOG), Case C-212/04, ECR 2006, I-06057, \$ 110.

48 See e.g. Judgment of the Court of 13 July 2000, Case C-456/98, Centrosteel Srl v. Adipol GmbH, ECR 2000, I-06007, § 15; Judgment of the Court of 12 December 1996, Joined cases C-74/95 and C-129/95, Criminal proceedings against X, ECR 1996, Page I-06609, $\$ 24$.

49 See e.g. Judgment of the Court of 8 October 1987, Case C-80/86, Criminal proceedings against Kolpinghuis Nijmegen BV., ECR 1987, Page 03969, \$ 9; Judgment of the Court of 14 July 1994, Case C-91/92, Paola Faccini Dori v. Recreb Srl., ECR 1994, I-3325, § 22; Judgment of the Court of 7 March 1996, Case C-192/94, El Corte Inglés SA v. Cristina Blázquez Rivero, ECR 1996, I-01281, $\$ 16$.

50 See Judgments of the Court in the Cases: M. H. Marshall v. Southampton and South-West Hampshire Area Health Authority (Teaching), Case 152/84, ECR 1986, Page 00723, § 48; Paola Faccini Dori v. Recreb Srl., Case 91/92, ECR 1994, I-3325, § 20 ff., $₫ 30$; The Queen, on the application of Delena Wells v. Secretary of State for Transport, Local Government and the Regions, Case C-201/02, ECR 2004, I-00723, \$ 56; Bernhard Pfeiffer and others v. Deutsches Rotes Kreuz, Kreisverband Waldshut eV., Joined Cases C-397/01 to C-403/01, ECR 2004, I-08835, $\S 108-109$. 
Internal and External Limits of the Principle of Consistent Interpretation of Domestic...

is typical for triangular relations between subjects of administrative law norms (e.g. in building law or environmental law cases).

\section{The internal limits of pro-directive interpretation}

The limits of the pro-directive interpretation can as well be derived from the domestic law of the member states. These limits may be called "the internal limits of pro-directive interpretation". However, the direct normative basis of these limits results from the national law, it is necessary to remind that the conceptual framework of interpretative limitations has been constructed by the ECJ.

According to the settled case-law of the ECJ (CJEU), on the one hand the Member States' obligation to achieve the result envisaged by the directive and their duty to take all appropriate measures, whether general or particular, is binding on all the authorities of Member States, including, for matters within their jurisdiction, the courts $^{51}$. On the other hand, national courts are obliged to interpret the domestic law, as far as possible, in the light of the wording and the purpose of the directive so as to achieve the result sought by the directive and consequently comply with the EU law ${ }^{52}$. From the above construction formula could be derived two internal limits of the prodirective interpretation of domestic law.

Firstly, the national court's obligation of the pro-directive interpretation covers only these matters and competence actions which are established within its jurisdiction. The limit of this kind is based on the assumption that the scope of judicial powers is confined by the constitutional and statutory principles which define the structural and competence position of the courts in relation to the legislature and the executive power. This limit is also strictly connected with the domestic limits of the judicial interpretation. Since judicial lawmaking operations - within certain limits - are permitted by the legal orders of member states, the notion of interpretation shall embrace as well interpretative results of the domestic law which go beyond the literal meaning of provisions. However, these judicial interpretative operations and their results cannot violate constitutional rules and principles $^{53}$ (e.g. the principle of separation of powers between the judiciary and the legislature, the principle of subordination of judges to the constitution and statutes).

51 See e.g. Judgment of the Court of 5 October 2004, in joined Cases C-397/01 to C-403/01, Bernhard Pfeiffer and others v. Deutsches Rotes Kreuz, Kreisverband Waldshut eV., ECR 2004, I-08835, $\$ 114$.

52 See Judgments of the Court in the Cases: Case 14/83, Sabine von Colson and Elisabeth Kamann v. Land Nordrhein-Westfalen, ECR 1984, Page 01891, \$26; Marleasing, § 8; Faccini Dori, § 26; Case C-63/97 BMW, ECR 1999, I-905, § 22; Joined Cases C-240/98 to C-244/98 Océano Grupo Editorial and Salvat Editores, ECR 2000, I-4941, §30; Case C-408/01 Adidas-Salomon and Adidas Benelux, ECR 2003, I-0000, paragraph 21. 
Secondly, it should be noted that the national court applying the provisions of domestic law intended to implement the directive is obliged to interpret those provisions so far as possible in such a way that they are applied in conformity with the objectives of the directive ${ }^{54}$. The principle of interpretation in conformity with EU law requires the court "to do whatever lies within its jurisdiction, having regard to the whole body of rules of national law" 55 and "applying the interpretative methods recognised by domestic law" ${ }^{\prime 6}$, to ensure the full effectiveness of the directive.

The notion of pro-directive interpretation "as far as possible" must be understood by that as meaning that the national court is bound to use all legally possible and permissible methods of interpretation in order to achieve the result sought by the directive. However, the EU law does not oblige the national court to construe the domestic law contra legem ${ }^{57}$, it cannot be unnoticed that the contra legem prohibition has a functional character ${ }^{58}$ and its boundaries are defined by the domestic interpretation rules which determine the position of the literal meaning of the legal text. Within the above approach the interpretation which goes beyond the literal meaning of domestic provisions could not be treated as being contrary to the domestic law. In the case-law of administrative courts the necessity of functional, purposive and axiological meaning of the contra legem limit is especially significant. Controlling the legality of the administrative action (e.g. administrative decision) the administrative court is often empowered and obliged to ensure the full correctness and effectiveness of the directive's implementation by means of the lawmaking interpretation of domestic law. The court can particularly make interpretative operations of extension or reduction of the normative contents of the domestic law (e.g. reducing the scope of tax obligation or expanding the scope of tax relief).

54 See Judgment of the Court of 13 November 1990, Case C-106/89, Marleasing v. La Comercial Internacional de Alimentación, ECR 1990, I-4135, \$ 8-13 and other judgments - e.g. Judgments of the Court in the Cases: Wagner Miret v. Fondo de Garantía Salarial, Case C-334/92, ECR 1993, I-6911, \$ 20; Faccini Dori, \$ 26; Océano Grupo Editorial v. Salvat Editores, Joined Cases C-240/98 to C-244/98, ECR 2000, I-4941, \$30.

55 Judgment of the Court of 15 April 2008, Case C-268/06, Impact v. Minister for Agriculture and Food and Others, ECR 2008, I-02483, \$ 118.

56 Judgment of the Court of 10 October 2013, Case C-306/12, Spedition Welter GmbH v. Avanssur SA, ECR 2013, § 32, ECLI:EU:C:2013:650.

57 E.g. Judgment of the Court of 16 June 2005, Case C-105/03, Criminal proceedings against Maria Pupino, ECR 2005 I-05285, § 47; Judgment of the Court of 15 April 2008, Case C-268/06, Impact v. Minister for Agriculture and Food and Others, ECR 2008, I-02483, \$ 103; Judgment of the Court of 4 July 2006, Case C-212/04, Konstantinos Adeneler and Others v. Ellinikos Organismos Galaktos (ELOG), ECR 2006, I-06057, \$ 110.

M. Brenncke, A Hybrid Methodology..., op. cit., p. 18. 
Internal and External Limits of the Principle of Consistent Interpretation of Domestic...

\section{Conclusions}

Consequently, one must accept the view that the pro-directive interpretation is permissible not only in typical situations of interpretation intra legem/secundum legem ("within the law"), but also in such situations where there is a necessity to construct the legal meaning of domestic provisions in conformity with the directive by means of interpretation praeter legem ("outside of the law" i.e. beyond the literal meaning of domestic provisions). This kind of quasi-lawmaking or even lawmaking judicial operations is an exemplification of the doctrine of law developing (the German term "die Rechtsfortbildung"). Since the ECJ (CJEU) "follows the French doctrine and does not distinguish between interpretation and development" 59 of the law (the French terminology: interprétation et justification), it is justified to state that the consistent interpretation must embrace operations of interpretation secundum legem and praeter legem. Therefore, the contra legem limit is "not fully determined by domestic law". The EU rules of interpretation shaping and confining the domestic interpretative methods establish a new "hybrid methodology" for consistent interpretation ${ }^{60}$.

Accordingly, it must be concluded that the interpretation which goes beyond the literal meaning of domestic law in order to ensure the full effectiveness of European Union law is compatible with the doctrine of the contra legem prohibition.

\section{BIBLIOGRAPHY}

Adinolfi A., The "Procedural Autonomy" of Member States and the Constraints Stemming from the ECJ's Case Law: Is Judicial Activism Still Necessary?, (in:) B. de Witte, H.-W. Micklitz (eds.), The European Court of Justice and Autonomy of the Member States, Cambridge - Antwerp Portland 2011.

Barnard C., Peers S., European Union Law, Oxford 2017.

Brechmann W., Die richtlinienkonforme Auslegung, München 1994.

Brenncke M., A Hybrid Methodology for the EU Principle of Consistent Interpretation, "Statute Law Review" 2017, vol. 38, forthcoming Issue, available at SSRN: https://papers.ssrn.com/, id $=2883447$ (access 1.11.2017).

Brzeziński P., Unijny obowiązek odmowy zastosowania przez sąd krajowy ustawy niezgodnej z dyrektywą Unii Europejskiej, Warszawa 2010.

Canaris C.-W., Gemeinsamkeiten zwischen verfassungs- und richtlinienkonformer Rechtsfindung, (in:) H. Bauer (ed.), Wirtschaft im offenen Verfassungsstaat. Festschrift für Reiner Schmidt zum 70. Geburtstag, München 2006

Craig P., Directives: Direct Effect, Indirect Effect and the Construction of National Legislation, "European Law Review" 1997, vol. 22.

59 M. Klatt, Making the Law Explicit. The Normativity of Legal Argumentation, Oxford and Portland 2008, pp. 16 ff.

60 M. Brenncke, A Hybrid Methodology..., op. cit., pp. 20, 33. 
Craig P., G. de Burca, EU Law. Text, Cases and Materials, Oxford 2011.

Craig P., The Legal Effect of Directives: Policy, Rules and Exceptions, "European Law Review" 2009, vol. 34 .

Ehricke U., Die richtlinienkonforme und die gemeinschaftsrechtskonforme Auslegung nationalen Rechts, "Rabels Zeitschrift für ausländisches und internationales Privatrecht" 1995, vol. 59.

M. Franzen, Privatrechtsangleichung durch die Europäische Gemeinschaft, Berlin - New York 1999.

Galetta D.-U., Procedural autonomy of EU member states: Paradise Lost? A study on the "functionalized procedural competence" of EU member states, Berlin - Heidelberg 2010.

Gänswein O., Der Grundsatz unionsrechtskonformer Auslegung nationalen Rechts. Erscheinungsformen und dogmatische Grundlage eines Rechtsprinzips des Unionsrechts, Frankfurt am Main 2009.

Herrmann C., Richtlinienumsetzung durch Rechtsprechung, Berlin 2003.

Höpfner C., Die systemkonforme Auslegung. Zur Auflösung einfachgesetzlicher, verfassungsrechtlicher und europarechtlicher Widersprüche im Recht, Tübingen 2008.

Jans J.H., De Lange R., Prechal S., Widdershoven R.J.G.M. (eds.), Europeanisation of Public Law, Groningen 2007.

Kaczorowska A., European Union Law, London - New York 2009.

Kalisz A., Wykładnia i stosowanie prawa wspólnotowego, Warszawa 2007.

Kamiński M., Mechanizm i granice weryfikacji sądowoadministracyjnej a normy prawa administracyjnego i ich konkretyzacja, Warszawa 2016.

Klatt M., Making the Law Explicit. The Normativity of Legal Argumentation, Oxford and Portland 2008

Kruis T., Der Anwendungsvorrang des EU-Rechts in Theorie und Praxis: seine Durchsetzung in Deutschland. Eine theoretische und empirische Untersuchung anhand der Finanz- und Verwaltungsgerichte und Behörden, Tübingen 2013.

Lutter M., Die Auslegung des angeglichenen Rechts, “Juristen-Zeitung” 1992, no. 47.

Nettesheim M., Auslegung und Rechtsfortbildung nationalen Rechts im Lichte des Gemeinschaftsrechts, "Archiv des öffentlichen Rechts" 1994, vol. 119.

Prechal S., Directives in EC Law, Oxford - New York 2005.

Timmermans C.W.A., Directives: their effect within the national legal systems, "Common Market Law Review" 1979, vol. 16.

Weber M., Grenzen EU-rechtskonformer Auslegung und Rechtsfortbildung, Baden - Baden 2010.

Wróbel A., Wykładnia prawa państwa członkowskiego zgodnie z dyrektywą, czyli tzw. pośredni skutek dyrektywy, (in:) A. Wróbel (ed.), Stosowanie prawa Unii Europejskiej przez sądy. Tom I, Warszawa 2010.

Wróbel A., Autonomia proceduralna państw członkowskich. Zasada efektywności i zasada efektywnej ochrony sądowej w prawie Unii Europejskiej, "Ruch Prawniczy, Ekonomiczny i Socjologiczny" 2005, no. 1 . 